\title{
Methane production, ruminal fermentation characteristics, nutrient digestibility, nitrogen excretion, and milk production of dairy cows fed conventional or brown midrib corn silage
}

\author{
F. Hassanat, ${ }^{*}$ R. Gervais, $†$ and C. Benchaar*1 \\ *Agriculture and Agri-Food Canada, Sherbrooke Research and Development Centre, 2000 College Street, Sherbrooke, QC, Canada J1M 0C8 \\ †Département des Sciences Animales, Université Laval, 2425, rue de l'Agriculture, Quebec, QC, Canada G1V 0A6
}

\begin{abstract}
The objective of this study was to examine the effect of replacing conventional corn silage (CCS) with brown midrib corn silage (BMCS) in dairy cow diets on enteric $\mathrm{CH}_{4}$ emission, nutrient intake, digestibility, ruminal fermentation characteristics, milk production, and $\mathrm{N}$ excretion. Sixteen rumen-cannulated lactating cows used in a crossover design (35-d periods) were fed (ad libitum) a total mixed ration (forage:concentrate ratio $=65: 35$, dry matter basis) based (59\% dry matter) on either CCS or BMCS. Dry matter intake and milk yield increased when cows were fed BMCS instead of CCS. Of the milk components, only milk fat content slightly decreased when cows were fed the BMCS-based diet compared with when fed the CCS-based diet (3.81 vs. $3.92 \%$ ). Compared with CCS, feeding BMCS to cows increased yields of milk protein and milk fat. Ruminal $\mathrm{pH}$, protozoa numbers, total VFA concentration, and molar proportions of acetate and propionate were similar between cows fed BMCS and those fed CCS. Daily enteric $\mathrm{CH}_{4}$ emission $(\mathrm{g} / \mathrm{d})$ was unaffected by dietary treatments, but $\mathrm{CH}_{4}$ production expressed as a proportion of gross energy intake or on milk yield basis was lower for cows fed the BMCS-based diet than for cows fed the CCS-based diet. A decline in manure $\mathrm{N}$ excretion and a shift in $\mathrm{N}$ excretion from urine to feces were observed when BMCS replaced CCS in the diet, suggesting reduced potential of manure $\mathrm{N}$ volatilization. Results from this study show that improving fiber quality of corn silage in dairy cow diets through using brown midrib trait cultivar can reduce enteric $\mathrm{CH}_{4}$ emissions as well as potential emissions of $\mathrm{NH}_{3}$ and $\mathrm{N}_{2} \mathrm{O}$ from manure. However, $\mathrm{CH}_{4}$ emissions during manure storage may increase due to excretion of degradable OM when BMCS diet is fed, which merits further investigation.
\end{abstract}

Received August 11, 2016.

Accepted December 11, 2016.

${ }^{1}$ Corresponding author: chaouki.benchaar@agr.gc.ca
Key words: methane, $\mathrm{N}$ excretion, brown midrib corn silage, conventional corn silage

\section{INTRODUCTION}

The agricultural sector contributes to greenhouse gas emissions through emissions related to enteric fermentation, manure management, and crop cultivation processes. The global contribution of this sector was estimated at $5.3 \mathrm{Gt}$ of $\mathrm{CO}_{2}$ equivalents, with $40 \%$ of these emissions from enteric fermentation and $7 \%$ from manure management (Tubiello et al., 2014). According to Environment Canada (2015), national agricultural emissions were estimated at $60 \mathrm{Mt}$ of $\mathrm{CO}_{2}$ equivalents, 42 and $6 \%$ are in form of $\mathrm{CH}_{4}$ from enteric fermentation and manure management, respectively. Mitigating $\mathrm{CH}_{4}$ emission would therefore lessen the agriculture environmental footprint and reduce energy losses from the farm production cycle.

Forages are the main component of dairy cow diets. Recent studies have shown that $\mathrm{CH}_{4}$ emitted [as a proportion of gross energy (GE) intake] varied with the source of forages used in the diet (Brask et al., 2013; Hassanat et al., 2013; Benchaar et al., 2014). For dairy cows fed forage-based diets, up to $7 \%$ of ingested GE could be lost as $\mathrm{CH}_{4}$ (Kebreab et al., 2008). Corn silage is one of the most popular forage sources of dairy cow diets in North America. Incorporating corn silage in dairy cow diets increases starch supply and, consequently, makes the conditions of the rumen environment less propitious to ruminal methanogenesis (Hassanat et al., 2013; Benchaar et al., 2014). However, increasing dietary corn silage proportion has been associated with milk fat depression in some studies (Brito and Broderick, 2006; Hassanat et al., 2013). This negative effect could be alleviated by increasing fiber digestibility of corn silage using brown midrib trait.

Compared with conventional corn silage (CCS) cultivar, brown midrib corn silage (BMCS) is characterized by lower lignin concentration and higher rumen potentially digestible NDF (Oba and Allen, 
2000a; Ebling and Kung, 2004; Gehman et al., 2008). Results from different studies showed an increase in DMI when BMCS replaced CCS in the diet of dairy cows (Ferraretto and Shaver, 2015). Increased DMI due to higher NDF digestibility has been associated with a high ruminal passage rate (Oba and Allen, 2000b; Sousa et al., 2014). Others (Okine et al., 1989; Hammond et al., 2014) showed that a faster ruminal passage rate is generally associated with a reduction in enteric $\mathrm{CH}_{4}$ production $(\mathrm{g} / \mathrm{kg}$ of $\mathrm{DMI}$ or as a percentage of GE intake). Based on these considerations (lower lignin concentration and higher ruminal fiber degradability of BMCS compared with CCS), we hypothesized that replacing CCS with BMCS in dairy cow diets would increase DMI and milk yield and decrease the amount of $\mathrm{CH}_{4}$ emitted per kilogram of DMI or kilogram of milk. Studies on the effect of using BMCS in dairy cow diets on enteric $\mathrm{CH}_{4}$ production are very scarce. Thus, the objective of our study was to fill this knowledge gap by assessing the effect of replacing CCS with BMCS in dairy cow diets on enteric $\mathrm{CH}_{4}$ production, digestion, ruminal fermentation characteristics, $\mathrm{N}$ excretion, milk production, and milk composition.

\section{MATERIALS AND METHODS}

The study was conducted at the Sherbrooke Research and Development Centre, (Sherbrooke, Quebec, Canada). Animal procedures were conducted under the approval of the local Institutional Animal Care Committee and were in accordance with the guidelines of the Canadian Council on Animal Care (CCAC, 1993).

\section{Corn Silage Cultivars and Silage Production}

The 2 corn silage cultivars were grown in the Sherbrooke Research and Development Centre in Quebec $\left(45^{\circ} 22^{\prime} \mathrm{N} 71^{\circ} 49^{\prime} \mathrm{W}\right)$. Corn silage conventional cultivar (Pride A4631, Pride Seeds, Chatham, ON, Canada) and a brown midrib cultivar (Mycogen F2F297, Mycogen Seeds, Indianapolis, IN) were seeded in a loam soil at 79,000 seeds/ha on May 6, 2013. The area received $691 \mathrm{~mm}$ of rain with an average temperature of $15.8^{\circ} \mathrm{C}$ during the growing season. Average 30-yr rain and temperature are $577 \mathrm{~mm}$ and $15.1^{\circ} \mathrm{C}$, respectively. Fields were fertilized with 170,73 , and $151 \mathrm{~kg} / \mathrm{ha}$ of $\mathrm{N}, \mathrm{P}_{2} \mathrm{O}_{5}$, and $\mathrm{K}_{2} \mathrm{O}$, respectively. Cultivation processes (tillage, fertilization, weed control, harvest) were similar between the 2 cultivars, which were harvested on the last week of September 2013 at a targeted $35 \%$ of whole-plant DM. The 2 cultivars were cut to a $20 \mathrm{~mm}$ theoretical chop length, inoculated with Lactobacillus buchneri (Biotal buchneri40788, Lallemand Animal Nu- trition, Milwaukee, WI), and then ensiled in bag silos (60 $\mathrm{m}$ long, $2.7 \mathrm{~m}$ diameter) for $4.5 \mathrm{mo}$ before being fed to animals.

\section{Cows, Experimental Design, and Diets}

Sixteen multiparous lactating Holstein cows fitted with rumen cannulas $(10 \mathrm{~cm}$, Bar Diamond Inc., Parma, ID) were grouped by DIM and milk yield and used in a crossover design ( 2 periods; $35 \mathrm{~d} /$ period). At the start of the study, cows averaged (mean \pm SD) 119 \pm 27 DIM with BW of $691 \pm 77 \mathrm{~kg}$ and milk yield of $43.5 \pm 6.4 \mathrm{~kg} / \mathrm{d}$. During the experiment, cows were housed in individual tiestalls, had free access to water, and fed (ad libitum; $5 \%$ orts on an as-fed basis) a TMR (65:35, forage:concentrate ratio) based on either CCS or BMCS (59\% of dietary DM). Chemical composition and ensiling characteristics of the 2 silages and diet composition (chemical and ingredient) are shown in Tables 1 and 2, respectively.

After $14 \mathrm{~d}$ of adaptation to dietary treatments, feed intake, apparent total-tract digestibility, $\mathrm{N}$ excretion, milk production, milk composition (i.e., $7 \mathrm{~d}$ ), in sacco ruminal degradability (i.e., $5 \mathrm{~d}$ ), rumen fermentation characteristics (i.e., 2 d), cow $\mathrm{BW}$ (i.e., 2 d), and $\mathrm{CH}_{4}$ production (i.e., $5 \mathrm{~d}$ ) were measured. Because only 2 air flow-controlled chambers were available, cows were staggered by $6 \mathrm{~d}$ to facilitate measurements. In addition, measurements (i.e., digestibility; $\mathrm{N}$ excretion; ru-

Table 1. Chemical composition of conventional and brown midrib corn silages

\begin{tabular}{|c|c|c|}
\hline \multirow[b]{2}{*}{ Item } & \multicolumn{2}{|c|}{ Corn silage cultivar } \\
\hline & Conventional & $\begin{array}{l}\text { Brown } \\
\text { midrib }\end{array}$ \\
\hline \multicolumn{3}{|l|}{ Chemical composition } \\
\hline DM $(\%)$ & 40.4 & 34.3 \\
\hline $\mathrm{OM}(\% \mathrm{DM})$ & 96.5 & 96.6 \\
\hline $\mathrm{CP}(\% \mathrm{DM})$ & 5.54 & 6.54 \\
\hline Soluble CP (\% CP) & 59.9 & 66.1 \\
\hline NDF (\% DM) & 34.3 & 34.4 \\
\hline $\mathrm{ADF}(\% \mathrm{DM})$ & 20.1 & 20.1 \\
\hline $\mathrm{ADL}(\% \mathrm{DM})$ & 2.71 & 2.11 \\
\hline Starch $(\% \mathrm{DM})$ & 26.9 & 28.3 \\
\hline Ether extract (\% DM) & 2.38 & 2.49 \\
\hline \multicolumn{3}{|l|}{ Ensiling characteristics } \\
\hline $\mathrm{pH}$ & 4.17 & 4.04 \\
\hline Lactic acid (\% DM) & 5.73 & 6.46 \\
\hline Acetic acid (\% DM) & 1.70 & 2.35 \\
\hline Propionic acid (\% DM) & $\mathrm{ND}^{1}$ & ND \\
\hline Butyric acid (\% DM) & ND & ND \\
\hline Ammonia-N (\% DM) & 0.12 & 0.16 \\
\hline Ethanol (\% DM) & 0.39 & 0.76 \\
\hline Water-soluble carbohydrates (\% DM) & 1.69 & 2.03 \\
\hline
\end{tabular}


Table 2. Ingredient and chemical composition of the experimental diets

\begin{tabular}{lcc}
\hline & \multicolumn{2}{c}{ Diet $^{1}$} \\
\cline { 2 - 3 } Item (\% of DM, unless otherwise noted) & CCS & BMCS \\
\hline Ingredient & & \\
Conventional corn silage & 58.8 & - \\
Brown midrib corn silage & - & 58.7 \\
Soybean meal, 48\% solvent extracted & 17.3 & 17.4 \\
Corn gluten feed & 10.6 & 10.7 \\
Timothy hay, chopped & 6.6 & 6.6 \\
Corn grain, ground & 2.1 & 2.1 \\
Soybean hulls & 1.8 & 1.8 \\
Mineral and vitamin supplement & \\
Calcium carbonate & 1.6 & 1.6 \\
Potassium carbonate & 0.7 & 0.7 \\
Chemical composition & 0.5 & 0.5 \\
OM & & \\
CP & 94.1 & 94.4 \\
NDF & 15.9 & 15.5 \\
ADF & 35.1 & 35.1 \\
ADL & 19.7 & 19.8 \\
Starch & 2.22 & 1.94 \\
Ether extract & 16.5 & 17.0 \\
Gross energy (Mcal/kg of DM) & 2.69 & 2.76 \\
\hline
\end{tabular}

${ }^{1} \mathrm{CCS}=$ conventional corn silage; BMCS $=$ brown midrib corn silage. ${ }^{2}$ Contained $12.48 \% \mathrm{Ca}, 6.80 \% \mathrm{P}, 6.81 \% \mathrm{~S}, 7.72 \% \mathrm{Na}, 1.97 \% \mathrm{~K}, 96 \mathrm{mg} /$ $\mathrm{kg}$ of I, $2,877 \mathrm{mg} / \mathrm{kg}$ of Fe, $620 \mathrm{mg} / \mathrm{kg}$ of Cu, 2,520 mg/kg of Mn, 3,777 $\mathrm{mg} / \mathrm{kg}$ of Zn, $83 \mathrm{mg} / \mathrm{kg}$ of Co, 628,000 IU $/ \mathrm{kg}$ of vitamin A, 81,000 $\mathrm{IU} / \mathrm{kg}$ of vitamin D, 3,739 IU/ $\mathrm{kg}$ of vitamin E, and $27.8 \mathrm{mg} / \mathrm{kg}$ of Se.

men fermentation; in sacco ruminal degradability; and $\mathrm{CH}_{4}$ ) were spread over the $21 \mathrm{~d}$ of sampling and data collection. As a consequence, for a given measurement, sampling and data collection did not occur on the same days for all cows. Accordingly, for all cows, $\mathrm{CH}_{4}$ measurements were completed between d 14 and 25 and rumen fluid sampling between d 22 and 27 , whereas milk production, digestibility, $\mathrm{N}$ excretion, and in sacco measurements were completed between d 26 and 34 . Cows were weighed at the beginning and the end of each experimental period before the a.m. feeding and after the a.m. milking.

\section{Intake, Apparent Total-Tract Digestibility, and $\mathrm{N}$ Excretion}

Apparent total-tract digestibility and $\mathrm{N}$ excretion were measured as described in Benchaar et al. (2013). Diets were offered in equal amounts twice daily (0900 and $1930 \mathrm{~h}$ ) and feed consumption was recorded daily by weighing feeds offered to and refused by the cows. Samples of the experimental diets, feed ingredients, and refusals were collected daily and stored at $-20^{\circ} \mathrm{C}$. These samples were later thawed, composited by cow within period, freeze-dried, ground to pass a 1-mm screen using a Wiley mill (standard model 4; Arthur M. Thomas, Philadelphia, PA), and analyzed for DM,
OM, total N, NDF, ADF, ADL, starch, ether extract, and GE. Samples of the 2 silages were further analyzed for lactic acid, VFA, ethanol, $\mathrm{NH}_{3}$, and water-soluble carbohydrates. Total collection of feces and urine was performed, as described in Benchaar et al. (2013), by fitting cows with harnesses and tubes allowing the collection of feces and urine separately. Feces were analyzed for DM, OM, total N, NDF, ADF, starch, and GE. Urine was analyzed for total N content.

\section{In Sacco Ruminal Degradability}

Ruminal degradability of CCS and BMCS was determined (6 cows; crossover design) using nylon bag procedure as described in Hassanat et al. (2013). Silages were freeze-dried, ground to pass a 2-mm screen using a Wiley mill, and 5-g samples (DM) were weighed in triplicate in polyester bags $(17 \times 9 \mathrm{~cm} ; 53 \mu \mathrm{m}$ pore size $)$ made of monofilament PeCAP Polyester (Sefar Nitex, Sefar AG, Heiden, Switzerland). Bags were incubated in the ventral sac of the rumen for $2,4,8,16,24,48$, 72,96 , and $120 \mathrm{~h}$. Bags used for time 0 disappearance were soaked in water at $37^{\circ} \mathrm{C}$ for $5 \mathrm{~min}$ and then treated similar to the other bags.

Kinetics of ruminal degradation of DM of CCS and BMCS were calculated using a nonlinear model (McDonald, 1981). The NLIN procedure of SAS (SAS Institute Inc., Cary, NC) was used to fit the following model:

$$
\begin{gathered}
\mathrm{P}=a+b\left(1-\mathrm{e}^{-c(\mathrm{t}-\mathrm{L})}\right) \text { for } \mathrm{t}>\mathrm{L} ; \\
\mathrm{P}=a \text { for } \mathrm{t} \leq \mathrm{L},
\end{gathered}
$$

where $\mathrm{P}=$ percentage of $\mathrm{DM}$ disappearance from the nylon bag at time t, $a=$ soluble and rapidly degradable fraction (\%), $b=$ slowly degradable fraction (\%), $\mathrm{e}=$ exponential, $c=$ fractional rate of disappearance of fraction $b(/ \mathrm{h}), \mathrm{L}=$ lag time $(\mathrm{h})$, and $\mathrm{t}=$ time of incubation (h). The model was fitted using $(a+b)$ $\leq 100, b \geq 0, c \geq 0$, and $\mathrm{L} \geq 0$ constraints.

The effective ruminal degradability (ERD) of DM was calculated using the equation

$$
\mathrm{ERD}=a+\left[b c /\left(c+\mathrm{k}_{\mathrm{p}}\right)\right] \times \mathrm{e}^{\left(-\mathrm{k}_{\mathrm{p}} \mathrm{L}\right)}
$$

where $\mathrm{k}_{\mathrm{p}}$ is the ruminal fractional passage rate, calculated at $0.05 / \mathrm{h}$ from the equations suggested by the NRC (2001) for wet forages. Residues of $24 \mathrm{~h}$ of incubation were ground to pass through a 1-mm screen and stored for subsequent measurement of NDF to determine 24-h in situ NDF ruminal degradability. 


\section{Ruminal Fermentation Characteristics and Protozoa Enumeration}

Ruminal fluid was collected from each cow before $(0$ h) and at 1, 2, 4, 6, and $8 \mathrm{~h}$ after the a.m. feeding. A total of $250 \mathrm{~mL}$ was collected from several locations within the rumen using a 50-mL syringe screwed to a stainless tube ending with a probe covered by a fine metal mesh (RT Rumen Fluid Collection Tube, Bar Diamond Inc.). Ruminal fluid was subsampled (12 mL) and frozen at $-20^{\circ} \mathrm{C}$ immediately for later determination of VFA concentrations. Another subsample (12 $\mathrm{mL}$ ) was acidified to $\mathrm{pH} 2$ with $50 \%$ sulfuric acid and frozen at $-20^{\circ} \mathrm{C}$ for later determination of $\mathrm{NH}_{3}$ concentrations.

Ruminal $\mathrm{pH}$ was measured continuously for $48 \mathrm{~h}$ using Kahne Bolus system (KB1000, Kahne Limited, Auckland, New Zealand), as described in Hassanat et al. (2013). The $\mathrm{pH}$ data were summarized as mean $\mathrm{pH}$, minimum $\mathrm{pH}$, maximum $\mathrm{pH}$, time spent below $\mathrm{pH}$ 6.0, time spent below $\mathrm{pH} 5.6$, and time spent below $\mathrm{pH} 5.2$ (Plaizier et al., 2001; Keunen et al., 2002; Khafipour et al., 2009).

Protozoa were counted from ruminal content collected at $4 \mathrm{~h}$ after the a.m. feeding. Ruminal content (approximately $1 \mathrm{~L}$ ) was strained through 4 layers of cheesecloth and a $5-\mathrm{mL}$ portion of the strained ruminal fluid was preserved using $5 \mathrm{~mL}$ of methyl green formalin-saline solution for protozoa enumeration (Ogimoto and Imai, 1981). Protozoa samples were stored at room temperature in darkness until counting. Protozoa were microscopically enumerated using a counting chamber (Neubauer Improved Bright-Line counting cell, $0.1 \mathrm{~mm}$ depth; Hausser Scientific, Horshamm, PA) and genera were identified as outlined by Dehority (1993).

\section{Milk Production and Milk Composition}

Cows were milked twice daily at 0700 and $1900 \mathrm{~h}$ in their stalls and milk production was recorded at each milking. During urine and feces collection days, milk samples were collected from each cow at each milking, stored at $4^{\circ} \mathrm{C}$ with a preservative (2-bromo2-nitropropan-1,3-diol), and sent to a commercial laboratory (Valacta Dairy Production Center of Expertise Quebec-Atlantic, Ste-Anne-de-Bellevue, QC, Canada) for analyses of fat, protein, lactose, MUN, and SCC.

\section{Enteric Methane Production}

Two air flow-controlled chambers were used for measurement of $\mathrm{CH}_{4}$ production. The chambers measured $4.09 \mathrm{~m}$ in length $\times 2.95 \mathrm{~m}$ in width $\times 2.84 \mathrm{~m}$ in height.
When chambers doors were closed, air entered the chamber through a ventilation duct and exited through an exhaust. Air temperature within the chamber was maintained at $18 \pm 1^{\circ} \mathrm{C}$. Air flow into and out of the chamber was measured using inline mass flowmeters (FT2; Fox Thermal Instruments Inc., Marina, CA) and maintained at $180 \pm 10 \mathrm{~m}^{3} / \mathrm{h}$. Methane concentration was continuously measured at the air entrance and exhaust ducts using $\mathrm{CH}_{4}$ analyzers (MGA3000; ADC Gas Analysis Ltd., Hoddesdon, Hertfordshire, UK). The amount of $\mathrm{CH}_{4}$ (entering and leaving the chamber) was calculated by multiplying the concentration of $\mathrm{CH}_{4}$ by the airflow (at entrance and at exhaust). The difference between the incoming and outgoing mass of $\mathrm{CH}_{4}$ corresponded to the amount of enteric $\mathrm{CH}_{4}$ emitted in each chamber by the animal. The chambers were calibrated at the beginning of each experimental period by releasing known amounts of $\mathrm{CH}_{4}$ in each chamber (with no cow inside). The recovered amounts were calculated from the difference incoming and outgoing $\mathrm{CH}_{4}$. The recovered amounts ranged from 98 to $102 \%$. The calibration factors (i.e., to adjust each chamber to $100 \%$ recovery) were used to correct $\mathrm{CH}_{4}$ emissions data. A small positive pressure was generated inside each chamber to prevent inflow of gases into the chambers. Methane was recorded every minute and fluxes were averaged to derive $24-\mathrm{h} \mathrm{CH}_{4}$ emissions. Cows were preconditioned to the environmental chambers before the beginning of the experiment. To reduce the effect of isolation on animal behavior, the chambers were equipped with windows and speakers so the cow in the chamber could see and hear other cows. Cows entered the chambers $18 \mathrm{~h}$ before starting $\mathrm{CH}_{4}$ measurements. Within each chamber, the cow was kept in a tiestall that measured $1.82 \mathrm{~m}$ long $\times 1.60 \mathrm{~m}$ wide, elevated from the floor by $25 \mathrm{~cm}$. Manure was collected from each cow in a stainless box placed below and to the rear of each stall. Farm personnel accessed the chambers twice daily (0800 and $2000 \mathrm{~h}$ ) to feed and milk the cows and remove the manure. The doors were kept opened for a maximum of 1 to $1.5 \mathrm{~min}$ to allow exchange of material in and out of the chambers. This resulted in interruptions of flux measurements for 15 to $30 \mathrm{~min}$, which is the time required for gas concentrations to reach steady state. These interruptions had a little effect on daily emissions because fluxes were calculated every minute and used to derive the 24-h period emissions values. Cows in the chambers were milked twice daily, had free access to water, and were fed twice daily for ad libitum intake (5\% orts on an as-fed basis). Offered feed and orts were weighed daily to determine feed consumption. Samples of feed offered and orts were collected, pooled across days, and kept frozen for later determination of DM and GE concentrations. 


\section{Chemical Analyses}

Dry matter content was determined by drying samples in a vacuum oven at $100^{\circ} \mathrm{C}$ overnight (AOAC, 1990; method 934.01). Ash content was determined by sample incineration at $550^{\circ} \mathrm{C}$ overnight in a muffle furnace (AOAC, 1990; method 942.05), and the OM content was calculated as the difference between 100 and the percentage of ash. Crude protein $(\mathrm{N} \times 6.25)$ was determined using the macro-Kjeldahl procedure (AOAC, 1990; method 990.03). The concentration of NDF was determined as described by Van Soest et al. (1991) with the use of sodium sulfite and with the inclusion of heatstable $\alpha$-amylase. The ADF and ADL contents were determined according to AOAC (1990; method 973.18). The NDF, ADF, and ADL procedures were adapted for use in an Ankom200 Fiber Analyzer (Ankom Technology Corp., Fairport, NY). The concentration of starch was determined colorimetrically according to the procedure of Hall et al. (2001). Ether extract was determined using the Soxtec 2050 extraction systems (Foss, Höganäs, Sweden) according to AOAC (1990; method 920.39). Gross energy was determined using an oxygen bomb calorimeter (model 6200, Parr Instrument Company, Moline, IL). The concentration of $\mathrm{N}$ in acidified urine samples was determined by micro-Kjeldahl analysis (AOAC, 1990). Water-soluble silage extracts were analyzed for water-soluble carbohydrates (Dubois et al., 1956), VFA, lactic acid (Taylor, 1996), and ethanol (GLC; model 6850, Agilent Technologies, Mississauga, ON, Canada). Analysis of VFA was performed using a gas chromatograph equipped with a flame ionization detector and auto-injector (6850 network GC system, Agilent Technologies) fitted with DB-FFAP column (30 $\mathrm{m} \times 0.250 \mathrm{~mm} \times 0.25 \mu \mathrm{m}$; Agilent Technologies), as in Benchaar et al. (2015). Ammonia concentration was determined as in Weatherburn (1967). Protein, fat, lactose, urea N, and SCC in milk samples were analyzed by infrared spectroscopy (MilkoScan FT 6000; Foss Electric, Hillerød, Denmark). Milk composition was corrected for differences in milk yield between a.m. and p.m. milking.

\section{Statistical Analyses}

Data were analyzed using the MIXED procedure of SAS (SAS Institute Inc.), and the statistical model included diet and period as fixed effects whereas cow was considered as random effect. Ruminal fermentation characteristics (i.e., VFA, $\mathrm{NH}_{3}$, protozoa) data were analyzed as repeated measures using the same model with the addition of the fixed effects of day, sampling time (i.e., hour), and all interactions. The $\mathrm{CH}_{4}$ data were also analyzed as repeated measures with the inclu- sion of the fixed effects of day and day $\times$ treatment interaction. The appropriate covariance structure used for repeated-measures analyses was chosen according to the type of repeated measurement (single or double), sampling distance (equal or unequal), and to achieve lowest Akaike, corrected Akaike, and Bayesian information criteria values. The covariance structure used cow within treatment $\times$ period as subject of the repeated measures. In sacco ruminal degradability data were analyzed as a crossover design and the model included the fixed effects of diet, silage incubated (BMCS or CCS), diet $\times$ silage interaction, and period whereas cow was the random effect. Significant effects of treatment were declared at $P \leq 0.05$ whereas tendencies were declared at $0.05<P \leq 0.10$.

\section{RESULTS}

\section{Silage and Diet Composition}

Chemical composition and ensiling characteristics of the 2 experimental silages are presented in Table 1. Silage from BMCS had lower DM and slightly higher (1 percentage unit) CP concentration than CCS. Concentrations of starch, NDF, and ADF were similar between CCS and BMCS (27.6, 34.4, and 20.1\%, respectively), but ADL concentration was $22 \%$ lower in BMCS than in CCS. The low $\mathrm{pH}$ of the 2 silages (average 4.1), the elevated concentration of lactic acid, and the undetectable concentration of butyric acid point to well preserved silages.

Ingredients and chemical composition of the 2 experimental diets are shown in Table 2. Conventional corn silage and BMCS were the major component of the experimental diets ( $59 \%$ of dietary DM). Proportion (35\% DM) and composition (ingredients) of the concentrate was similar between the 2 diets. The experimental diets contained (on DM basis) similar concentrations of CP (16\%), NDF (35\%), ADF (20\%), starch (17\%), ether extract $(2.73 \%)$, and GE (4.4 Mcal $/ \mathrm{kg})$.

\section{Intake and Apparent Total-Tract Digestibility of Nutrients}

Feeding cows the BMCS-based diet increased DMI by $1.6 \mathrm{~kg} / \mathrm{d}(P<0.01)$ compared with feeding the CCSbased diet (Table 3). Because fiber, starch, and GE concentrations were similar among the 2 experimental diets, this increase in DMI resulted in higher $(P \leq 0.02)$ intakes of fiber, starch, and GE in cows fed the BMCSbased diet compared with cows fed the CCS-based diet. In contrast, $\mathrm{CP}$ intake was not affected by the dietary corn silage cultivar. 
Table 3. Intake and apparent total-tract digestibility of nutrients of lactating cows fed diets based on conventional (CCS) or brown midrib (BMCS) corn silage

\begin{tabular}{lcccr}
\hline & \multicolumn{2}{c}{ Diet } & & \\
\cline { 2 - 3 } Item & CCS & BMCS & SEM & P-value \\
\hline Intake (kg/d, unless otherwise noted) & & & & \\
DM & 25.8 & 27.4 & 0.67 & $<0.01$ \\
DM $(\%$ BW) & 3.70 & 3.90 & 0.072 & 0.01 \\
OM & 24.2 & 25.9 & 0.64 & $<0.01$ \\
CP & 4.15 & 4.27 & 0.110 & 0.11 \\
NDF & 8.88 & 9.56 & 0.235 & 0.02 \\
ADF & 4.97 & 5.38 & 0.147 & 0.04 \\
Starch & 4.31 & 4.65 & 0.117 & $<0.01$ \\
Gross energy (Mcal/d) & 112 & 120 & 3.0 & $<0.01$ \\
Digestibility (\%) & & & & \\
DM & 70.1 & 69.4 & 0.48 & 0.20 \\
OM & 71.6 & 71.0 & 0.46 & 0.21 \\
CP & 73.2 & 71.1 & 0.68 & $<0.01$ \\
NDF & 54.4 & 53.4 & 1.01 & 0.51 \\
ADF & 53.8 & 54.0 & 1.19 & 0.90 \\
Starch & 98.1 & 97.8 & 0.16 & 0.03 \\
Gross energy & 69.3 & 68.7 & 0.51 & 0.23 \\
\hline
\end{tabular}

Digestibility of DM (69.8\%), OM (71.3\%), NDF (53.9\%), ADF (53.9\%), and GE (69.0\%) was not affected by silage cultivar of the diet. A decline $(P \leq 0.03)$ in CP (2 percentage units) and starch (0.3 percentage units) digestibility was observed when BMCS replaced CCS in the diet.

\section{Ruminal Degradability of Silages}

Dry matter ruminal degradability parameters of CCS and BMCS are presented in Table 4. The soluble and rapidly degradable fraction and slowly degradable fraction were higher $(P<0.01)$ for BMCS than for CCS. Fractional degradation rate and lag time were not different between CCS and BMCS and averaged 0.017/h and $1.8 \mathrm{~h}$, respectively. Effective ruminal degradability was higher $(P<0.01)$ for BMCS than for CCS $(64.0$ vs. $60.8 \%$ ). The 24 -h ruminal degradability of NDF was

Table 4. Dry matter and 24-h NDF ruminal degradation of conventional (CCS) and brown midrib (BMCS) corn silage incubated in the rumen of lactating cows fed diets based on CCS or BMCS

\begin{tabular}{|c|c|c|c|c|}
\hline \multirow[b]{2}{*}{ Item $^{1}$} & \multicolumn{2}{|c|}{ Diet } & \multirow[b]{2}{*}{ SEM } & \multirow[b]{2}{*}{$P$-value } \\
\hline & $\mathrm{CCS}$ & BMCS & & \\
\hline \multicolumn{5}{|l|}{ DM } \\
\hline$a(\%)$ & 51.3 & 53.2 & 0.20 & $<0.01$ \\
\hline$b(\%)$ & 39.0 & 42.3 & 0.91 & $<0.01$ \\
\hline$c(/ \mathrm{h})$ & 0.017 & 0.017 & 0.0014 & 0.88 \\
\hline Lag time $(\mathrm{h})$ & 2.04 & 1.54 & 0.736 & 0.66 \\
\hline $\operatorname{ERD}(\%)$ & 60.8 & 64.0 & 0.23 & $<0.01$ \\
\hline NDF degradation (\%) & 18.1 & 23.8 & 0.96 & $<0.01$ \\
\hline
\end{tabular}

${ }^{1} a=$ soluble and rapidly degradable fraction; $b=$ slowly degradable fraction; $c=$ fractional rate of disappearance of the fraction $b$; ERD $=$ effective ruminal degradability. higher $(P<0.01)$ for BMCS than for CCS $(23.8$ vs. $18.1 \%)$.

\section{Ruminal Fermentation Characteristics}

No significant interactions between sampling day or sampling time and treatment were observed for any of the ruminal fermentation characteristics. Therefore, only averages of the 2-d measurements at different sampling times were reported (Tables 5 and 6). Daily ruminal $\mathrm{pH}$ averaged 6.3 and was not affected by corn silage cultivar (Table 5). However, minimum ruminal $\mathrm{pH}$ was lower $(P=0.03)$ in cows fed the BMCS-based diet than in cows fed the CCS-based diet (5.6 vs. 5.8). Duration of ruminal $\mathrm{pH}<6.0$ averaged $169 \mathrm{~min} / \mathrm{d}$ and was not affected by silage cultivar, whereas duration of ruminal $\mathrm{pH}<5.6$ was negligible for both experimental diets.

Total VFA concentration, molar proportions of acetate, propionate, and butyrate and the acetate:propionate ratio averaged $117 \mathrm{mM}, 58 \%, 25 \%, 12 \%$ and 2.38 , re-

Table 5. Ruminal $\mathrm{pH}$ characteristics of lactating dairy cows fed diets based on conventional (CCS) or brown midrib (BMCS) corn silage

\begin{tabular}{lcccc}
\hline & \multicolumn{2}{c}{ Diet } & & \\
\cline { 2 - 3 } Item & CCS & BMCS & SEM & $P$-value \\
\hline $\mathrm{pH}$ & 6.31 & 6.26 & 0.026 & 0.21 \\
Mean & 5.80 & 5.64 & 0.042 & 0.03 \\
Minimum & 6.84 & 6.85 & 0.028 & 0.46 \\
Maximum & 120 & 218 & 42.3 & 0.19 \\
Time $\mathrm{pH}<6.0(\mathrm{~min} / \mathrm{d})$ & 6 & 7 & 3.7 & 0.61 \\
Time $\mathrm{pH}<5.6(\mathrm{~min} / \mathrm{d})$ & 0 & 0 & - & - \\
Time $\mathrm{pH}<5.2(\mathrm{~min} / \mathrm{d})$ & 0 & & & \\
\hline
\end{tabular}


Table 6. Total VFA concentration, VFA molar proportions, $\mathrm{NH}_{3}$ concentration, and protoza number of ruminal fluid of lactating dairy cows fed diets based on conventional (CCS) or brown midrib (BMCS) corn silage

\begin{tabular}{|c|c|c|c|c|}
\hline \multirow[b]{2}{*}{ Item } & \multicolumn{2}{|c|}{ Diet } & \multirow[b]{2}{*}{ SEM } & \multirow[b]{2}{*}{$P$-value } \\
\hline & CCS & BMCS & & \\
\hline Total VFA $(\mathrm{m} M)$ & 116 & 118 & 2.2 & 0.51 \\
\hline \multicolumn{5}{|l|}{ VFA $(\mathrm{mol} / 100 \mathrm{~mol})$} \\
\hline Acetate & 58.6 & 57.6 & 0.84 & 0.12 \\
\hline Propionate & 25.1 & 25.6 & 0.98 & 0.56 \\
\hline Butyrate & 11.8 & 12.3 & 0.32 & 0.17 \\
\hline Valerate & 1.75 & 1.96 & 0.139 & 0.02 \\
\hline Branched-chain VFA ${ }^{1}$ & 2.79 & 2.54 & 0.096 & 0.04 \\
\hline Acetate:propionate ratio & 2.42 & 2.33 & 0.123 & 0.34 \\
\hline $\mathrm{NH}_{3}(\mathrm{~m} M)$ & 13.7 & 10.3 & 0.43 & $<0.01$ \\
\hline \multicolumn{5}{|l|}{ Protozoa $\left(\right.$ cell $\left.\times 10^{3} / \mathrm{mL}\right)$} \\
\hline Total & 622 & 587 & 94.9 & 0.54 \\
\hline Entodiniomorphs & 617 & 584 & 94.0 & 0.56 \\
\hline Holotrichs $^{2}$ & 5.21 & 3.33 & 1.219 & 0.10 \\
\hline Isotrichs & 4.69 & 3.28 & 1.124 & 0.17 \\
\hline Dasytrichs & 0.52 & 0.05 & 0.204 & 0.07 \\
\hline
\end{tabular}

${ }^{1}$ Branched-chain VFA $=$ isobutyrate + isovalerate.

${ }^{2}$ Holotrichs $=$ isotrichs and dasytrichs.

spectively, and were not affected by corn silage cultivar (Table 6). However, valerate molar proportion was higher $(P=0.02)$ in cows fed the BMCS-based diet compared with cows fed the CCS-based diet. Feeding the BMCS-based diet lowered $(P \leq 0.04)$ ruminal $\mathrm{NH}_{3}$ concentration (10.3 vs. $13.7 \mathrm{mM}$ ) and molar proportion of branched-chain VFA (2.54 vs. $2.79 \%$ ) compared with feeding the CCS-based diet. Total protozoa population was unaffected $\left(6.0 \times 10^{5}\right.$ cell $\left./ \mathrm{mL}\right)$ by corn silage cultivar. Among protozoa genera identified, only holotrichs tended to decrease $(P=0.10)$ when BMCS replaced CCS in the diet, and this decrease was mainly due to a reduction in dasytrichs numbers $(P=0.07)$.

\section{Milk Production and Milk Composition}

Data of milk production and milk composition determined over the 7-d collection period are shown in Table 7. Compared with feeding the CCS-based diet, feeding the BMCS-based diet increased $(P<0.01)$ milk yield by $3 \mathrm{~kg} / \mathrm{d}$. Values of milk yield determined in the chambers were slightly higher $(35.7$ and $39.0 \mathrm{~kg} / \mathrm{d}$ for CCS and BMCS, respectively; data not shown) than those determined during the 7-d collection period (34.6 and $37.8 \mathrm{~kg} / \mathrm{d}$ for CCS and BMCS, respectively). However, difference in milk yield between treatments was similar when measured during the 7 -d collection period $(+3.3$ $\mathrm{kg} / \mathrm{d})$ versus in the chambers $(+3.2 \mathrm{~kg} / \mathrm{d})$. Milk protein and lactose concentrations were unaffected by the source of silage (3.5 and $4.6 \%$, respectively). A minor but significant decline (0.1 percentage unit; $P=0.05$ ) in milk fat concentration was observed when BMCS replaced CCS in the diet. Concentration of MUN was lower $(P<0.01)$ in cows fed the BMCS-based than in cows fed the CCS-based diet (15.8 vs. $19.2 \mathrm{mg} / \mathrm{dL})$. Yields of milk fat and milk protein increased $(P<0.01)$ when the BMCS-based diet was fed compared with the CCS-based diet (1.43 vs. 1.35 and 1.31 vs. $1.21 \mathrm{~kg} / \mathrm{d}$, respectively). Yields of FCM and ECM were $3 \mathrm{~kg} / \mathrm{d}$ higher $(P<0.01)$ for cows fed the BMCS-based diet than cows fed the CCS-based diet. Feed efficiency (kilogram of milk, FCM, or ECM per kilogram of DMI) was not affected by corn silage cultivar fed. Efficiency of $\mathrm{N}$ utilization for milk production (milk $\mathrm{N} / \mathrm{N}$ intake) increased $(P<0.01)$ when BMCS replaced CCS in the $\operatorname{diet}(0.302$ vs 0.286$)$.

\section{Enteric Methane Production}

No interaction between treatments and measurement day was observed for $\mathrm{CH}_{4}$ variables. Therefore, only averages across measurement days were reported (Table 8). Enteric $\mathrm{CH}_{4}$ emission averaged $476 \mathrm{~g} / \mathrm{d}$ and was not affected by corn silage cultivar. When expressed on DMI basis, $\mathrm{CH}_{4}$ emission was lower $(P=0.05)$ for cows fed the BMCS-based diet than for cows fed the CCS-based $\operatorname{diet}(17.2$ vs. $18.4 \mathrm{~g} / \mathrm{kg}$ of DMI). Similarly, the amount of $\mathrm{CH}_{4}$ emitted per kilogram of $\mathrm{OM}$ digested tended $(P=0.06)$ to decrease when cows were fed the BMCSbased compared with the CCS-based diet (25.6 vs. 27.8

Table 7. Milk production and milk composition of lactating cows fed diets based on conventional (CCS) or brown midrib (BMCS) corn silage

\begin{tabular}{|c|c|c|c|c|}
\hline \multirow[b]{2}{*}{ Item } & \multicolumn{2}{|c|}{ Diet } & \multirow[b]{2}{*}{ SEM } & \multirow[b]{2}{*}{$P$-value } \\
\hline & CCS & BMCS & & \\
\hline \multicolumn{5}{|l|}{ Production $(\mathrm{kg} / \mathrm{d})$} \\
\hline Milk & 34.6 & 37.8 & 1.57 & $<0.01$ \\
\hline $4 \% \mathrm{FCM}^{1}$ & 34.1 & 36.6 & 1.50 & $<0.01$ \\
\hline $\mathrm{ECM}^{2}$ & 37.5 & 40.4 & 1.60 & $<0.01$ \\
\hline \multicolumn{5}{|l|}{ Composition } \\
\hline Fat $(\%)$ & 3.92 & 3.81 & 0.106 & 0.05 \\
\hline Protein (\%) & 3.52 & 3.49 & 0.056 & 0.40 \\
\hline Lactose (\%) & 4.62 & 4.64 & 0.036 & 0.18 \\
\hline MUN (mg/dL) & 19.2 & 15.8 & 0.51 & $<0.01$ \\
\hline $\operatorname{SCC}\left(\log _{10} / \mathrm{mL}\right)$ & 4.06 & 4.08 & 0.371 & 0.79 \\
\hline \multicolumn{5}{|l|}{ Yield (kg/d) } \\
\hline Fat & 1.35 & 1.43 & 0.063 & $<0.01$ \\
\hline Protein & 1.21 & 1.31 & 0.048 & $<0.01$ \\
\hline Lactose & 1.60 & 1.76 & 0.079 & $<0.01$ \\
\hline \multicolumn{5}{|l|}{ Feed efficiency } \\
\hline Milk/DMI & 1.34 & 1.39 & 0.057 & 0.15 \\
\hline FCM/DMI & 1.32 & 1.34 & 0.045 & 0.42 \\
\hline ECM/DMI & 1.45 & 1.48 & 0.048 & 0.32 \\
\hline Milk $\mathrm{N} / \mathrm{N}$ intake & 0.286 & 0.302 & 0.010 & $<0.01$ \\
\hline
\end{tabular}

${ }^{1} 4 \%$ FCM $($ Tyrrell and Reid, 1965) $=0.4 \times$ milk yield $(\mathrm{kg} / \mathrm{d})+15 \times$ fat yield $(\mathrm{kg} / \mathrm{d})$.

${ }^{2} \mathrm{ECM}($ Tyrrell and Reid, 1965$)=0.327 \times$ milk yield $(\mathrm{kg} / \mathrm{d})+12.95$ $\times$ fat yield $(\mathrm{kg} / \mathrm{d})+7.2 \times$ protein yield $(\mathrm{kg} / \mathrm{d})$. 
$\mathrm{g} / \mathrm{kg}$ OM digested). Methane energy losses expressed as a percentage of GE intake were also lower $(P=0.05)$ for cows fed the BMCS-based diet than the CCS-based diet (5.16 vs. $5.52 \%$ ). Likewise, $\mathrm{CH}_{4}$ losses expressed on digestible energy intake tended to decrease $(P=0.08)$ when BMCS replaced CCS in the diet (7.50 vs. $7.97 \%$ digestible energy intake). Expressing $\mathrm{CH}_{4}$ emissions on milk yield basis showed lower emissions $(P=0.02)$ for cows fed the BMCS-based diet $(12.7 \mathrm{~g} / \mathrm{kg})$ compared with cows fed the CCS-based diet $(14.3 \mathrm{~g} / \mathrm{kg})$. Similar declines $(0.02 \leq P \leq 0.04)$ in $\mathrm{CH}_{4}$ emission expressed per kilogram of FCM, ECM, milk fat, or milk protein were observed when BMCS replaced CCS in the diet.

\section{Nitrogen Excretion}

Fecal $\mathrm{N}$ excretion $(\mathrm{g} / \mathrm{d}$ or $\%$ of $\mathrm{N}$ intake) increased $(P$ $<0.01)$, but urinary $\mathrm{N}$ excretion $(\mathrm{g} / \mathrm{d}$ or $\%$ of $\mathrm{N}$ intake) decreased $(P<0.01)$ when BMCS replaced CCS in the diet (Table 9). Total $\mathrm{N}$ excretion $(\mathrm{g} / \mathrm{d}$ or $\%$ of $\mathrm{N}$ intake) was lower $(P \leq 0.04)$ in cows fed the BMCSbased diet (479 g/d and 70\%, respectively) compared with cows fed the CCS-based diet $(497 \mathrm{~g} / \mathrm{d}$ and $75 \%$, respectively). Estimated $\mathrm{N}$ balance $(\mathrm{g} / \mathrm{d}$ and $\% \mathrm{~N}$ intake) was lower $(P \leq 0.05)$ for cows fed the CCS-based diet $(-22.6 \mathrm{~g} / \mathrm{d}$ and $-3.5 \%)$ compared with cows fed the BMCS-based diet $(-1.4 \mathrm{~g} / \mathrm{d}$ and $-0.5 \%)$.

\section{DISCUSSION}

Chemical composition of the 2 silages is within the range of values reported by Ferraretto and Shaver (2015) for DM (25.7-43.3\%), NDF (32.8-52.8\%), ADF (18.5-31.8\%), lignin (0.9-5.3\%), and starch (15.9$45.9 \%$ ). For unknown reasons, concentrations of CP of CCS and BMCS observed in our study (5.5 and 6.5\%, respectively) were lower than $\mathrm{CP}$ concentration of corn silage (6.8-8.0\%) used in our previous studies (Hassanat et al., 2013; Benchaar et al., 2014) and grown under similar conditions (seeding rate, fertilization rate, harvesting, and preservation) in the same location (i.e., Sherbrooke Research Centre). In sacco degradability parameters (DM) of CCS and BMCS observed in our study are within values reported for the soluble and rapidly degradable fraction (31 to 60\%), the slowly degradable fraction ( 25 to $52 \%$ ), the fractional rate of disappearance of the slowly degradable fraction $(0.016$ to $0.061 / \mathrm{h}$ ), and the effective ruminal degradability ( 54 to $66 \%$ ) in previous studies (Mustafa et al., 2005; Hassanat et al., 2013; Holt et al., 2016).

Replacing CCS with BMCS in the diet increased DMI by $1.6 \mathrm{~kg} / \mathrm{d}$ (i.e., $+6 \%$ ). Because fiber (NDF and ADF) content was similar among CCS and BMCS, the increase in $\mathrm{DMI}$ is more likely related to the lower $\mathrm{ADL}$
Table 8. Methane production of lactating cows fed diets based on conventional (CCS) or brown midrib (BMCS) corn silage

\begin{tabular}{|c|c|c|c|c|}
\hline \multirow[b]{2}{*}{ Item } & \multicolumn{2}{|c|}{ Diet } & \multirow[b]{2}{*}{ SEM } & \multirow[b]{2}{*}{$P$-value } \\
\hline & CCS & BMCS & & \\
\hline$\overline{\mathrm{DMI}^{1}(\mathrm{~kg} / \mathrm{d})}$ & 26.1 & 27.3 & 0.64 & $<0.01$ \\
\hline \multicolumn{5}{|l|}{$\mathrm{CH}_{4}$} \\
\hline $\mathrm{g} / \mathrm{d}$ & 483 & 470 & 21.4 & 0.43 \\
\hline $\mathrm{g} / \mathrm{kg}$ of DMI & 18.4 & 17.2 & 0.62 & 0.05 \\
\hline $\mathrm{g} / \mathrm{kg}$ of $\mathrm{OM}$ digested & 27.8 & 25.6 & 0.98 & 0.06 \\
\hline$\%$ GE intake ${ }^{2}$ & 5.52 & 5.16 & 0.186 & 0.05 \\
\hline$\%$ DE intake ${ }^{3}$ & 7.97 & 7.50 & 0.249 & 0.08 \\
\hline $\mathrm{g} / \mathrm{kg}$ of milk & 14.3 & 12.7 & 0.76 & 0.02 \\
\hline $\mathrm{g} / \mathrm{kg}$ of $\mathrm{FCM}^{4}$ & 14.4 & 13.0 & 0.67 & 0.02 \\
\hline $\mathrm{g} / \mathrm{kg}$ of $\mathrm{ECM}^{4}$ & 13.1 & 11.8 & 0.62 & 0.02 \\
\hline $\mathrm{g} / \mathrm{kg}$ of $\mathrm{milk}_{\mathrm{fat}}{ }^{4}$ & 363 & 333 & 16.1 & 0.04 \\
\hline $\mathrm{g} / \mathrm{kg}$ of milk protein ${ }^{4}$ & 406 & 365 & 20.1 & 0.02 \\
\hline
\end{tabular}

${ }^{1}$ Determined when cows were in the chambers.

${ }^{2} \mathrm{GE}=$ gross energy.

${ }^{3} \mathrm{DE}=$ digestible energy (estimated from energy digestibility measured over collection days).

${ }^{4}$ Yields of milk, FCM, ECM, milk fat, and milk protein measured over collection days.

concentration (2.11 vs. $2.71 \%$ ) and, consequently, the higher ruminal degradability of DM and NDF of BMCS compared with CCS. In agreement with our findings, in a recent meta-analysis Ferraretto and Shaver (2015) reported that BMCS had similar fiber concentration but lower lignin content and higher ruminal degradability of NDF (41\%) compared with CCS (37\%), which resulted into an increase of $1 \mathrm{~kg} / \mathrm{d}$ in DMI when dairy cows were fed BMCS-based diets compared with when fed CCS-based diets. Likewise, Oba and Allen (2000b) observed lower lignin concentration and higher in vitro NDF degradation $(+9 \%)$ of BMCS compared with CCS. These changes were associated with an increase in DMI $(+1.1 \mathrm{~kg} ;+7 \%)$ for cows fed BMCS-based diets compared with cows fed CCS-based diets. Oba and Allen (2000b) also observed faster ruminal passage rate in cows fed BMCS-based diets than in cows fed CCS-

Table 9. Nitrogen excretion in urine and feces of lactating cows fed diets based on conventional (CCS) or brown midrib (BMCS) corn silage

\begin{tabular}{lcccr}
\hline & \multicolumn{2}{c}{ Diet } & & \\
\cline { 2 - 3 } Item & CCS & BMCS & SEM & $P$-value \\
\hline Fecal N & & & & \\
g/d & 178 & 198 & 6.5 & $<0.01$ \\
\% of N intake & 26.8 & 28.9 & 0.68 & $<0.01$ \\
Urinary N & & & & \\
g/d & 319 & 282 & 8.9 & $<0.01$ \\
\% of N intake & 48.1 & 41.3 & 0.95 & $<0.01$ \\
Total N excretion & & & & \\
g/d & 497 & 479 & 13.8 & 0.04 \\
\% of N intake & 74.9 & 70.2 & 1.26 & $<0.01$ \\
\hline
\end{tabular}


based diets, which has probably reduced physical fill in the rumen and led to the observed increase in DMI.

An increase in daily enteric $\mathrm{CH}_{4}$ emission (g/d) would be expected when DMI increases (Beauchemin et al., 2009; Reynolds et al., 2011). In the current study, such a response in daily enteric $\mathrm{CH}_{4}$ production $(\mathrm{g} / \mathrm{d})$ did not occur despite the higher DMI observed for cows fed the BMCS-based diet compared with cows fed the CCS-based diet. However, when expressed per kilogram of DMI or as a proportion of GE intake, $\mathrm{CH}_{4}$ production was lower for cows fed the BMCS-based diet than the CCS-based diet. Because $\mathrm{CH}_{4}$ emissions $(\mathrm{g} / \mathrm{d})$ were unchanged and digestible OM increased for cows fed the BMCS-based diet versus the CCS-based diet (18.4 vs. $17.3 \mathrm{~kg} / \mathrm{d}, P=0.02$; respectively; data not shown), $\mathrm{CH}_{4}$ production expressed on digestible OM intake basis tended to be lower for cows fed the BMCS-based diet than for cows fed the CCS-based diet. In contrast, $\mathrm{CH}_{4}$ production was unaffected when expressed on digestible NDF basis because of similar $\mathrm{CH}_{4}$ emission and digestible NDF (4.98 kg/d; data not shown) among treatments. Studies investigating the effects of feeding CCS versus BMCS on enteric $\mathrm{CH}_{4}$ production of dairy cows are scarce. Similar to our findings, Tine et al. (2001) also reported higher DMI and lower $\mathrm{CH}_{4}$ energy losses (\% GE intake) when BMCS replaced CCS in the diet of lactating dairy cows. Schwarm et al. (2015) reported no change in $\mathrm{CH}_{4}$ emitted per kilogram of $\mathrm{OM}$ or NDF digested in heifers fed CCS versus BMCS.

In the current study, the decline in $\mathrm{CH}_{4}$ energy losses (\% of GE intake) observed for cows fed BMCS versus cows fed CCS is more likely due to faster ruminal passage rates. In several studies, higher ruminal passage rates have been associated with a decrease in $\mathrm{CH}_{4}$ energy losses (\% of GE intake). Okine et al. (1989) reported a $29 \%$ decrease in $\mathrm{CH}_{4}$ energy losses (\% of GE intake) when the fractional passage rates of liquid and particulate matter from the rumen were increased by 43 and $63 \%$, respectively, by placing weight in the rumen of beef cattle. Other recent studies (Pinares-Patiño et al., 2003; Goopy et al., 2014; Hammond et al., 2014) confirmed the inverse relationship between enteric $\mathrm{CH}_{4}$ production ( $\mathrm{g} / \mathrm{kg}$ of DMI or \% GE intake) and ruminal passage rates.

The higher DM and NDF ruminal degradability of BMCS compared with CCS should have resulted in increased apparent total-tract digestibility of DM and NDF in cows fed the BMCS-based diet compared with cows fed the CCS-based diet. However, these changes did not occur, as shown by similar DM and NDF apparent total-tract digestibility between cows fed the experimental treatments. This discrepancy between $24 \mathrm{~h}$ in sacco NDF degradation (higher for BMCS vs. CCS) and NDF total-tract digestibility (no change) may be due to the fact that in sacco measurements do not take into account possible change in retention time (i.e., passage rate) that may have occurred in vivo when BMCS replaced CCS in the diet. Other studies also reported no change in DM and NDF total-tract digestibility when BMCS replaced CCS in dairy cow diets (Oba and Allen, 2000b; Weiss and Wyatt, 2006; Holt et al., 2013). Oba and Allen (2000b) observed a reduction in ruminal digestion of OM that was compensated by higher digestion at postruminal sites, which resulted in similar total-tract digestibility of $\mathrm{OM}$ and fiber when BMCS replaced CCS in dairy cow diets.

Ruminal $\mathrm{pH}$, total VFA concentration, molar proportions of acetate, propionate, and butyrate, and protozoa numbers were not affected by the experimental treatments, which is consistent with the lack of dietary treatments on the amount of $\mathrm{CH}_{4}$ emitted daily by dairy cows. A meta-analysis by Ferraretto and Shaver (2015) revealed no effect of feeding BMCS versus CCS to dairy cows on ruminal $\mathrm{pH}$, total VFA concentration, and molar proportions of the major VFA, which agrees with our findings.

Despite similar CP intake between cows fed the BMCS-based diet and those fed the CCS-based diet, molar proportion of branched-chain VFA and ruminal concentration of $\mathrm{NH}_{3}$ decreased when the BMCS-based diet was fed compared with the CCS-based diet. Our findings are in agreement with results reported in previous studies (Greenfield et al., 2001; Gehman et al., 2008; Holt et al., 2013). A decline in ruminal $\mathrm{NH}_{3}$ concentration and branched-chain VFA molar proportion is an indication of an inhibition of the deamination process and increased capture of $\mathrm{N}$ (as $\mathrm{AA}$ or $\mathrm{NH}_{3}$ ) by rumen microbes (Hristov and Jouany, 2005). These changes in ruminal $\mathrm{N}$ metabolism may indicate a greater supply of AA and improved rumen microbial protein synthesis in cows fed the BMCS-based diet compared with the CCS-based diet (Oba and Allen, 2000b).

In the current study, milk production (actual, FCM, and ECM) was higher for cows fed the BMCS-based diet compared with cows fed the CCS-based diet, which is consistent with the higher DMI observed for cows fed the BMCS-based diet compared with the CCS-based diet. Previous studies also reported higher milk production for cows fed diets based on BMCS compared with diets based on CCS (Oba and Allen, 1999; Ebling and Kung, 2004; Kung et al., 2008). A meta-analysis of 48 peer-reviewed studies (Ferraretto and Shaver, 2015) showed higher FCM yield associated with an increase in DMI when BMCS replaced CCS in dairy cow diets.

Milk fat concentration declined slightly when BMCS replaced CCS in the diet, which was due to the higher milk yield (dilution effect) for cows fed the BMCSversus the CCS-based diet. However, milk fat yield 
increased when cows were fed the BMCS- versus the CCS-based diet, which agrees with results reported by Oba and Allen (1999). Kendall et al. (2009) examined the performance response of cows fed high- or lowdigestible NDF diets and, similar to what was observed in our study, reported higher yields of milk, milk fat, and milk protein for cows fed high- compared with lowdigestible NDF diets. These increases were related to higher intake of digestible carbohydrates and higher rumen microbial protein synthesis.

Milk protein yield was higher for cows fed the BMCSthan the CCS-based diet. The increase in milk protein yield may be related to an increase in AA supply as reflected by lower ruminal $\mathrm{NH}_{3}$ concentration, branchedchain VFA molar proportion, and MUN in cows fed the BMCS-based diet than for cows fed the CCS-based diet. Other studies reported higher $\mathrm{N}$ secretion in milk when BMCS replaced CCS in the diet (Oba and Allen, 1999, 2000a; Tine et al., 2001).

Due to higher milk yield and no change in $\mathrm{CH}_{4}$ daily emitted (g/d), emissions expressed on a milk, FCM, or ECM yield basis were reduced by about $10 \%$ in cows fed the BMCS-based diet compared with cows fed the CCS-based diet. The decline in $\mathrm{CH}_{4}$ production (as a percentage of GE intake) when BMCS replaced CCS in the diet may also have contributed to enhanced energy availability for milk production and, ultimately, reduced $\mathrm{CH}_{4}$ emissions per unit of milk. Methane emissions relative to milk produced is expected to decline as milk production increases (Beauchemin et al., 2009; Reynolds et al., 2011).

Efficiency of dietary $\mathrm{N}$ utilization for milk protein synthesis (milk N/N intake) was higher for cows fed the BMCS- compared with the CCS-based diet. Higher energy intake when BMCS replaced CCS in the diet (4.65 vs. $4.31 \mathrm{Mcal} / \mathrm{d} ; P<0.01)$ may have spared AA degradation for gluconeogenesis and, therefore, increased AA availability for milk production. Others (Weiss and Wyatt, 2006; Holt et al., 2013) also observed an increase in efficiency of $\mathrm{N}$ utilization for milk protein synthesis when BMCS replaced CCS in dairy cow diets.

Any dietary strategy aiming to mitigate $\mathrm{CH}_{4}$ emission of dairy cows must also take into account the possible effect on $\mathrm{N}$ losses in manure, in particular urinary $\mathrm{N}$, to ensure that the reduction of enteric $\mathrm{CH}_{4}$ emission is not counterbalanced by increased $\mathrm{N}_{2} \mathrm{O}$ and $\mathrm{NH}_{3}$ emissions. In our study, $\mathrm{N}$ excretion in feces $(\mathrm{g} / \mathrm{d}$ or as a proportion of $\mathrm{N}$ intake) was higher for cows fed the BMCS- compared with the CCS-based diet. This increase can be related to faster ruminal passage rates (as discussed above) and, consequently, to increased hindgut fermentation. Recycled urea can be used to support microbial growth in the hindgut, as pointed out by Lapierre and Lobley (2001) and Hristov et al.
(2011). This may increase $\mathrm{N}$ losses in feces and decrease apparent CP digestibility, because microbial protein produced during hindgut fermentation cannot be digested and reabsorbed. Higher fecal $\mathrm{N}$ excretion $(\mathrm{g} / \mathrm{d}$ or proportion of $\mathrm{N}$ intake) was also reported when BMCS replaced CCS in dairy cow diets (Tine et al., 2001; Gehman et al., 2008). Contrary to the effect of dietary treatments on fecal $\mathrm{N}$ excretion, excretion of $\mathrm{N}$ in urine ( $\mathrm{g} / \mathrm{d}$ or as a proportion of $\mathrm{N}$ intake) decreased when BMCS replaced CCS in the diet. This change is an indication of enhanced efficiency of $\mathrm{N}$ utilization by the animal, as illustrated by the observed decline in ruminal $\mathrm{NH}_{3}$ concentrations in cows fed the BMCS- versus the CCS-based diet. This decline may have reduced $\mathrm{NH}_{3}$ absorption through the rumen wall, its conversion into urea, and $\mathrm{N}$ excretion in urine. In agreement, other studies (Greenfield et al., 2001; Holt et al., 2013) reported lower urinary $\mathrm{N}$ losses when BMCS replaced CCS in dairy cow diets. The shift in $\mathrm{N}$ excretion from urine to feces and the decline in manure (urine + feces) $\mathrm{N}$ excretion when BMCS replaced CCS in the diet may reduce $\mathrm{N}$ volatilization from manure and the contribution of manure to total greenhouse gas emissions (FAO, 2006; Dijkstra et al., 2011).

\section{CONCLUSIONS}

The use of more digestible corn silage (i.e., BMCS vs. CCS) in the diet increased DMI and milk production and reduced $\mathrm{CH}_{4}$ emissions per unit of DMI, GE intake, or milk produced. Furthermore, feeding the BMCScompared with the CCS-based diet to cows reduced N excretion in manure and potential $\mathrm{N}$ volatilization by shifting $\mathrm{N}$ excretion from urine to feces. However, the potential of $\mathrm{CH}_{4}$ emissions from manure storage needs to be assessed because of increased volatile solid content (i.e., degradable OM excretion) in the manure of cows fed BMCS versus CCS. This study demonstrates that enteric $\mathrm{CH}_{4}$ emissions from dairy cows could be mitigated by improving fiber quality (reducing ADL concentration) of forages of the ration. The evaluation of replacing CCS with BMCS in dairy cow diets on $\mathrm{CH}_{4}$ emission from stored manure is currently under investigation.

\section{ACKNOWLEDGMENTS}

The authors are grateful to L. Croteau (technical assistance) and Steve Méthot (help with statistical analyses) and the barn crew (care of animals) from the Sherbrooke Research and Development Centre (Agriculture and Agri-Food Canada, Ottawa, ON, Canada). The funding support of Agriculture and Agri-Food Canada is gratefully acknowledged. 


\section{REFERENCES}

AOAC. 1990. Official Methods of Analysis. 15th ed. AOAC, Arlington, VA.

Beauchemin, K., T. A. McAllister, and S. McGinn. 2009. Dietary mitigation of enteric methane from cattle. CAB Rev. Perspect. Agric. Vet. Sci. Nutr. Nat. Resour. 4:1-18. https://doi.org/10.1079/ PAVSNNR20094035.

Benchaar, C., F. Hassanat, R. Gervais, P. Y. Chouinard, C. Julien, H. V. Petit, and D. I. Masse. 2013. Effects of increasing amounts of corn dried distillers grains with solubles in dairy cow diets on methane production, ruminal fermentation, digestion, $\mathrm{N}$ balance, and milk production. J. Dairy Sci. 96:2413-2427. https://doi. org/10.3168/jds.2012-6037.

Benchaar, C., F. Hassanat, R. Gervais, P. Y. Chouinard, H. V. Petit, and D. I. Masse. 2014. Methane production, digestion, ruminal fermentation, nitrogen balance, and milk production of cows fed corn silage- or barley silage-based diets. J. Dairy Sci. 97:961-974. https://doi.org/10.3168/jds.2013-7122.

Benchaar, C., F. Hassanat, R. Martineau, and R. Gervais. 2015. Linseed oil supplementation to dairy cows fed diets based on red clover silage or corn silage: Effects on methane production, rumen fermentation, nutrient digestibility, $\mathrm{N}$ balance, and milk production. J. Dairy Sci. 98:7993-8008. https://doi.org/10.3168/ jds.2015-9398.

Brask, M., P. Lund, A. L. F. Hellwing, M. Poulsen, and M. R. Weisbjerg. 2013. Enteric methane production, digestibility and rumen fermentation in dairy cows fed different forages with and without rapeseed fat supplementation. Anim. Feed Sci. Technol. 184:67-79. https://doi.org/10.1016/j.anifeedsci.2013.06.006.

Brito, A. F., and G. A. Broderick. 2006. Effect of varying dietary ratios of alfalfa silage to corn silage on production and nitrogen utilization in lactating dairy cows. J. Dairy Sci. 89:3924-3938. https:// doi.org/10.3168/jds.S0022-0302(06)72435-3.

CCAC. 1993. Guide to the Care and Use of Experimental Animals. Vol. 1. 2nd ed. Canadian Council on Animal Care (CCAC), Ottawa, ON, Canada.

Dehority, B. A. 1993. Laboratory Manual for Classification and Morphology of Rumen Ciliate Protozoa. CRC Press Inc., Boca Raton, FL.

Dijkstra, J., O. Oenema, and A. Bannink. 2011. Dietary strategies to reducing $\mathrm{N}$ excretion from cattle: Implications for methane emissions. Curr. Opin. Environ. Sustain. 3:414-422. https://doi. org/10.1016/j.cosust.2011.07.008.

Dubois, M., K. A. Gilles, J. K. Hamilton, P. A. Rebers, and F. Smith. 1956. Colorimetric method for determination of sugars and related substances. Anal. Chem. 28:350-356. https://doi.org/10.1021/ ac60111a017.

Ebling, T. L., and L. Kung Jr. 2004. A comparison of processed conventional corn silage to unprocessed and processed brown midrib corn silage on intake, digestion, and milk production by dairy cows. J. Dairy Sci. 87:2519-2526. https://doi.org/10.3168/jds. S0022-0302(04)73376-7.

Environment Canada. 2015. Greenhouse Gas Sources and Sinks in Canada, National Inventory Report 1990-2013 Part 3. Environment Canada, Ottawa, ON.

FAO. 2006. Livestock's Long Shadow. Chief, Electronic Publishing Policy and Support Branch Communication Division - Food and Agriculture Organization of the United Nations (FAO), Rome, Italy.

Ferraretto, L. F., and R. D. Shaver. 2015. Effects of whole-plant corn silage hybrid type on intake, digestion, ruminal fermentation, and lactation performance by dairy cows through a meta-analysis. J. Dairy Sci. 98:2662-2675. https://doi.org/10.3168/jds.2014-9045.

Gehman, A. M., P. J. Kononoff, C. R. Mullins, and B. N. Janicek. 2008. Evaluation of nitrogen utilization and the effects of monensin in dairy cows fed brown midrib corn silage. J. Dairy Sci. 91:288-300. https://doi.org/10.3168/jds.2007-0098.

Goopy, J. P., A. Donaldson, R. Hegarty, P. E. Vercoe, F. Haynes, M. Barnett, and V. H. Oddy. 2014. Low-methane yield sheep have smaller rumens and shorter rumen retention time. Br. J. Nutr. 111:578-585. https://doi.org/10.1017/S0007114513002936.
Greenfield, T. L., R. L. Baldwin, R. A. Erdman, and K. R. McLeod. 2001. Ruminal fermentation and intestinal flow of nutrients by lactating cows consuming brown midrib corn silages. J. Dairy Sci. 84:2469-2477. https://doi.org/10.3168/jds.S0022-0302(01)746978.

Hall, M. B., J. P. Jennings, B. A. Lewis, and J. B. Robertson. 2001. Evaluation of starch analysis methods for feed samples. J. Sci. Food. Agric. 81:17-21.

Hammond, K. J., D. Pacheco, J. L. Burke, J. P. Koolaard, S. Muetzel, and G. C. Waghorn. 2014. The effects of fresh forages and feed intake level on digesta kinetics and enteric methane emissions from sheep. Anim. Feed Sci. Technol. 193:32-43. https://doi. org/10.1016/j.anifeedsci.2014.04.005.

Hassanat, F., R. Gervais, C. Julien, D. I. Masse, A. Lettat, P. Y. Chouinard, H. V. Petit, and C. Benchaar. 2013. Replacing alfalfa silage with corn silage in dairy cow diets: Effects on enteric methane production, ruminal fermentation, digestion, $\mathrm{N}$ balance, and milk production. J. Dairy Sci. 96:4553-4567. https://doi.org/10.3168/ jds.2012-6480.

Holt, M. S., K. Neal, J. S. Eun, A. J. Young, J. O. Hall, and K. E. Nestor Jr.. 2013. Corn silage hybrid type and quality of alfalfa hay affect dietary nitrogen utilization by early lactating dairy cows. J. Dairy Sci. 96:6564-6576. https://doi.org/10.3168/jds.2013-6689.

Holt, M. S., S. Y. Yang, J. E. Creech, J. S. Eun, and A. J. Young. 2016. In situ ruminal degradation kinetics of corn silage hybrids harvested prior to or at maturity in dry and lactating dairy cows. J. Anim. Plant Sci. 26:46-53.

Hristov, A. N., M. Hanigan, A. Cole, R. Todd, T. A. McAllister, P. M. Ndegwa, and A. Rotz. 2011. Review: Ammonia emissions from dairy farms and beef feedlots. Can. J. Anim. Sci. 91:1-35. https:// doi.org/10.4141/cjas10034.

Hristov, A. N., and J. P. Jouany. 2005. Factors affecting the efficiency of nitrogen utilization in the rumen. Pages 117-166 in Nitrogen and Phosphorus Nutrition of Cattle: Reducing the Environmental Impact of Cattle Operations. CAB International, Cambridge, MA.

Kebreab, E., K. A. Johnson, S. L. Archibeque, D. Pape, and T. Wirth. 2008. Model for estimating enteric methane emissions from United States dairy and feedlot cattle. J. Anim. Sci. 86:2738-2748. https://doi.org/10.2527/jas.2008-0960.

Kendall, C., C. Leonardi, P. C. Hoffman, and D. K. Combs. 2009. Intake and milk production of cows fed diets that differed in dietary neutral detergent fiber and neutral detergent fiber digestibility. J. Dairy Sci. 92:313-323. https://doi.org/10.3168/jds.2008-1482.

Keunen, J. E., J. C. Plaizier, L. Kyriazakis, T. F. Duffield, T. M. Widowski, M. I. Lindinger, and B. W. McBride. 2002. Effects of a subacute ruminal acidosis model on the diet selection of dairy cows. J. Dairy Sci. 85:3304-3313. https://doi.org/10.3168/jds. S0022-0302(02)74419-6.

Khafipour, E., D. O. Krause, and J. C. Plaizier. 2009. Alfalfa pelletinduced subacute ruminal acidosis in dairy cows increases bacterial endotoxin in the rumen without causing inflammation. J. Dairy Sci. 92:1712-1724. https://doi.org/10.3168/jds.2008-1656.

Kung, L., Jr., B. M. Moulder, C. M. Mulrooney, R. S. Teller, and R. J. Schmidt. 2008. The effect of silage cutting height on the nutritive value of a normal corn silage hybrid compared with brown midrib corn silage fed to lactating cows. J. Dairy Sci. 91:1451-1457. https://doi.org/10.3168/jds.2007-0236.

Lapierre, H., and G. E. Lobley. 2001. Nitrogen recycling in the ruminant: A review. J. Dairy Sci. 84:E223-E236. https://doi. org/10.3168/jds.S0022-0302(01)70222-6.

McDonald, I. 1981. A revised model for the estimation of protein degradability in the rumen. J. Agric. Sci. 96:251-252.

Mustafa, A. F., P. Seguin, O. Marois-Mainguy, and D. R. Ouellet. 2005. Ensiling characteristics, nutrient composition, and in situ ruminal and whole tract degradability of brown midrib and leafy corn silage. Arch. Anim. Nutr. 59:353-363. https://doi. org/10.1080/17450390500247931.

NRC. 2001. Nutrient Requirements of Dairy Cattle. Natl. Acad. Press, Washington, DC.

Oba, M., and M. S. Allen. 1999. Effects of brown midrib 3 mutation in corn silage on dry matter intake and productivity of high yielding 
dairy cows. J. Dairy Sci. 82:135-142. https://doi.org/10.3168/jds. S0022-0302(99)75217-3.

Oba, M., and M. S. Allen. 2000a. Effects of brown midrib 3 mutation in corn silage on productivity of dairy cows fed two concentrations of dietary neutral detergent fiber: 1 . Feeding behavior and nutrient utilization. J. Dairy Sci. 83:1333-1341. https://doi.org/10.3168/ jds.S0022-0302(00)75000-4.

Oba, M., and M. S. Allen. 2000b. Effects of brown midrib 3 mutation in corn silage on productivity of dairy cows fed two concentrations of dietary neutral detergent fiber: 3. Digestibility and microbial efficiency. J. Dairy Sci. 83:1350-1358. https://doi.org/10.3168/jds. S0022-0302(00)75002-8.

Ogimoto, K., and S. Imai. 1981. Techniques of rumen microbiology. Page 158 in Atlas of Rumen Microbiology. Japan Sci. Soc. Press, Tokyo, Japan.

Okine, E. K., G. W. Mathison, and R. T. Hardin. 1989. Effects of changes in frequency of reticular contractions on fluid and particulate passage rates in cattle. J. Anim. Sci. 67:3388-3396.

Pinares-Patiño, C. S., R. Baumont, and C. Martin. 2003. Methane emissions by Charolais cows grazing a monospecific pasture of timothy at four stages of maturity. Can. J. Anim. Sci. 83:769-777. https://doi.org/10.4141/a03-034.

Plaizier, J. C., J. E. Keunen, J. P. Walton, T. F. Duffield, and B. W. McBride. 2001. Effect of subacute ruminal acidosis on in situ digestion of mixed hay in lactating dairy cows. Can. J. Anim. Sci. 81:421-423. https://doi.org/10.4141/a00-106.

Reynolds, C. K., L. A. Crompton, and J. A. N. Mills. 2011. Improving the efficiency of energy utilisation in cattle. Anim. Prod. Sci. 51:6-12. https://doi.org/10.1071/AN10160.

Schwarm, A., M. Schweigel-Röntgen, M. Kreuzer, S. Ortmann, F. Gill, B. Kuhla, U. Meyer, M. Lohölter, and M. Derno. 2015. Methane emission, digestive characteristics and faecal archaeol in heifers fed diets based on silage from brown midrib maize as compared to conventional maize. Arch. Anim. Nutr. 69:159-176. https://doi.or g/10.1080/1745039X.2015.1043211.

Sousa, D. O., B. S. Mesquita, J. Diniz-Magalhães, I. C. Bueno, L. G. Mesquita, and L. F. P. Silva. 2014. Effect of fiber digestibility and conservation method on feed intake and the ruminal ecosystem of growing steers. J. Anim. Sci. 92:5622-5634. https://doi. org/10.2527/jas.2014-8016.

Taylor, K. A. C. C. 1996. A simple colorimetric assay for muramic acid and lactic acid. Appl. Biochem. Biotechnol. 56:49-58. https://doi org/10.1007/bf02787869.

Tine, M. A., K. R. McLeod, R. A. Erdman, and R. L. t. Baldwin. 2001. Effects of brown midrib corn silage on the energy balance of dairy cattle. J. Dairy Sci. 84:885-895. https://doi.org/10.3168/jds. S0022-0302(01)74546-8.

Tubiello, F. N., M. Salvatore, R. D. Cóndor Golec, A. Ferrara, S. Rossi, R. Biancalani, S. Federici, H. Jacobs, and A. Flammini. 2014. Agriculture, Forestry and Other Land Use Emissions by Sources and Removals by Sinks 1990-2011 Analysis. Food and Agriculture Organization of the United Nations, Rome, Italy.

Tyrrell, H. F., and J. T. Reid. 1965. Prediction of the energy value of cow's milk. J. Dairy Sci. 48:1215-1223.

Van Soest, P. J., J. B. Robertson, and B. A. Lewis. 1991. Methods for dietary fiber, neutral detergent fiber, and nonstarch polysaccharides in relation to animal nutrition. J. Dairy Sci. 74:3583-3597. https://doi.org/10.3168/jds.S0022-0302(91)78551-2.

Weatherburn, M. 1967. Phenol-hypochlorite reaction for determination of ammonia. Anal. Chem. 39:971-974. https://doi.org/10.1021/ ac60252a045.

Weiss, W. P., and D. J. Wyatt. 2006. Effect of corn silage hybrid and metabolizable protein supply on nitrogen metabolism of lactating dairy cows. J. Dairy Sci. 89:1644-1653. https://doi.org/10.3168/ jds.S0022-0302(06)72231-7. 